\title{
Sample Viability Indicator
}

National Cancer Institute

\section{Source}

National Cancer Institute. Sample Viability Indicator. NCI Thesaurus. Code C139279.

An indication as to whether the sample contains viable cells or tissues. 